\title{
Peran Pengaruh Komite Dan Pengawas Terhadap Pengelolaan Dana Bos Di Sektor Sekolah Dasar Negeri
}

\author{
PO Abas Sunarya ${ }^{1}$, Meri Mayangsari ${ }^{2}$, Eduard Hotman Purba ${ }^{3}$ \\ Dosen Universitas Raharja ${ }^{1}$, Mahasiswa Akuntansi Universitas Raharja ${ }^{2}$, Dosen Universitas \\ Raharja $^{3}$
}

Jl. Jend. Sudirman No. 40, Modern Cikokol, Tangerang

Email:abas@raharja.info ${ }^{1)}$, meri.mayang@raharja.info ${ }^{2)}$, warseno@raharja.info ${ }^{3)}$

\begin{abstract}
Abstrak
Penelitian ini bertujuan untuk mengetahui pentingnya pengaruh peran komite dan pengawas terhadap pengelolaan dana BOS (Bantuan Operasional Sekolah) di sekolah dasar negeri. Dalam penelitian ini peneliti menggunakan metode kuantitatif. Sedangkan untuk responden penelitian adalah 158 orang guru yang mengajar di Sekolah Dasar di Kota Tangerang dan pengambilan sampelnya menggunakan rumus Slovin yang menghasilkan 115 responden. Teknik pengambilan sampel dilakukan dengan probability sampling. Data diperoleh dari data primer dengan menggunakan kuesioner, wawancara tidak terstruktur dan dokumentasi. Untuk analisis data, peneliti menggunakan regresi linier berganda dengan program SPSS versi 16.00 .

Hasil penelitian hipotesis menunjukkan bahwa variabel independen komite sekolah adalah $0,015<0,05$, sehingga berpengaruh signifikan terhadap pengelolaan dana BOS, peran pengawas sekolah $0,000<0,05$, berpengaruh signifikan terhadap pengelolaan dana BOS, sedangkan hasil uji $\mathrm{F}$ atau secara simultan 0,000 $<0,05$ yang artinya peran komite dan pengawas berpengaruh signifikan terhadap pengelolaan dana BOS. Kata kunci: Pengelolaan Dana BOS, Komite Sekolah, Pengawas Sekolah
\end{abstract}

\begin{abstract}
This study aims to determine the importance of the influence of the role of the committee and supervisors on the management of BOS (School Operational Assistance) funds in public elementary schools. In this study, researchers used quantitative methods. Meanwhile, the research respondents were 158 teachers who taught at elementary schools in Tangerang City and the samples were taken using the Slovin formula which resulted in 115 respondents. The sampling technique was carried out by using probability sampling. Data obtained from primary data using questionnaires, unstructured interviews and documentation. For data analysis, researchers used multiple linear regression with the SPSS version 16.00 program.

The results of the hypothesis research show that the independent variable of the school committee is $0.015<0.05$, so that it has a significant effect on the management of BOS funds, the role of school supervisors is $0.000<0.05$, has a significant effect on the management of BOS funds, while the results of the F test or simultaneously $0.000<0,05$ which means that the role of the committee and supervisor has a significant effect on the management of BOS funds.
\end{abstract}

Keywords: BOS Fund Management, School Committee, School Supervisor 


\section{Pendahuluan}

Setiap penyelenggaraan pendidikan dipandang penting sebagai sarana untuk nantinya dapat meningkatkan kualitas sumber daya manusia suatu bangsa. Berbagai kajian atau penelitian selalu dapat menunjukkan hubungan positif antara pendidikan dan pengembangan kualitas sumber daya manusia. pengentasan kemiskinan, dan meningkatkan laju pertumbuhan ekonomi. Kesimpulannya, generasi penerus bangsa Indonesia diharapkan mampu bersaing dan memiliki kompetensi yang unggul guna mewujudkan bangsa Indonesia yang maju, cerdas dan berintegritas.

Dalam pengadaan untuk meningkatkan efektivitas sekolah, pemerintah memberikan sumbangan dana untuk bantuan operasional ke sekolah. Salah satu bentuk bantuan pendidikan pemerintah bagi masyarakat adalah Dana BOS (Bantuan Operasional Sekolah). Dana BOS yang diberikan pemerintah nantinya dapat dikelola secara mandiri dan terbuka oleh sekolah untuk meningkatkan mutu dan kualitas pembelajaran. Adanya program yang dikeluarkan oleh pemerintah memerlukan pengawasan yang intensif guna meminimalisir risiko yang ada

Komite Sekolah dan Pengawas dalam hal ini adalah badan independen independen yang mewakili peran serta masyarakat dalam mengkaji mutu pendidikan, pemerataan pendidikan, dan efisiensi pengelolaan penyelenggara pendidikan [1]. Berdasarkan hasil penelitian, pengelolaan dana BOS merupakan program yang efektif. Dengan pengelolaan yang baik serta peran pengawas dan komite sekolah diharapkan tujuan bantuan operasional sekolah dapat tercapai dengan baik.

\section{Landasan Teori}

\section{Akuntansi Sektor Publik}

Mulyani, dkk [2], mengemukakan bahwa Akuntansi Sektor Publik adalah sistem akuntansi yang digunakan oleh lembaga publik sebagai sarana pertanggungjawaban kepada public.

\section{Komite Sekolah}

Irwan yang dikutip oleh Rahayu [3], mengemukakan bahwa komite sekolah merupakan lembaga independen dan tidak memiliki hubungan hierarki dengan sekolah atau lembaga pemerintah lainnya.

\section{Pengawas Sekolah}

Permenegpan dan RB Nomor 21 tahun 2010 yang dikutip oleh sitorus dan kholipah [4], menyatakan bahwa pengawas sekolah merupakan salah satu tenaga kependidikan yang berperan strategis dalam meningkatkan profesionalisme guru, kepala sekolah dan mutu pendidikan di sekolah.

\section{Pengelolaan Dana BOS}

Dana BOS dipandang sebagai alokasi dana dari pemerintah untuk memperhatikan hak-hak masyarakat dan berpihak pada masyarakat kecil untuk mendapatkan pendidikan dasar. Pasal 31 ayat 2 UUD 1945 dengan tegas menyatakan bahwa pemerintah bertanggung jawab membiayai pendidikan dasar dengan menyalurkan dana BOS. [5]

Dalam upaya memberikan gambaran tentang gagasan pokok suatu kajian skematik, peneliti membuat kerangka penelitian sebagai berikut: 


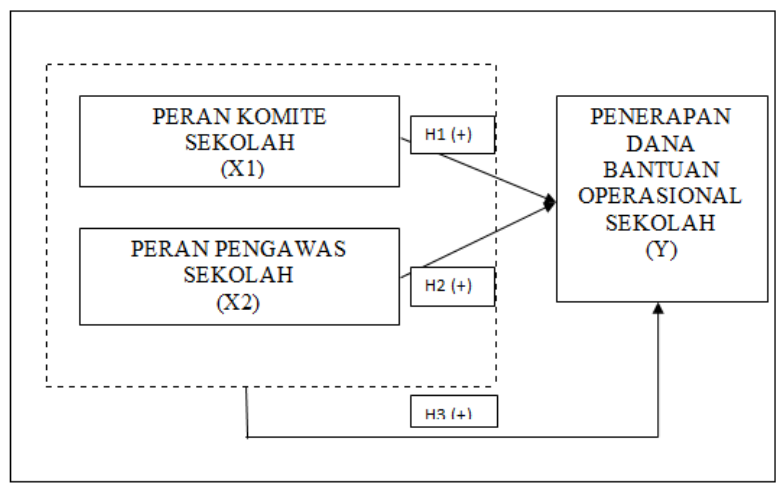

Gambar1 Skema Kerangka

H1: Peran Komite Sekolah yang berpengaruh signifikan terhadap pengelolaan dana BOS.

$\mathrm{H} 2$ : Peran pengawas sekolah yang berpengaruh signifikan terhadap pengelolaan dana BOS.

H3: Peran komite sekolah dan pengawas yang berpengaruh signifikan terhadap pengelolaan dana BOS.

\section{Literatur Review}

1. Indahri [6], "Peran Sekolah Dan Masyarakat Dalam Pelaksanaan Program Bantuan Operasional Sekolah". Penelitian dilakukan untuk melihat kendala yang dihadapi dalam pelaksanaan program dana BOS. Dan hasil yang didapat adalah penambahan alokasi anggaran perlu terus mendengarkan masukan dari pemerintah provinsi / kabupaten / kota, serta dari masyarakat agar penggunaan dana kepada masyarakat tidak memaksa.

2. Rukanto [7], "Pengaruh Peran Komite Sekolah Dan Program Bantuan Operasional Sekolah (Bos) Terhadap Mutu Pendidikan Di SMA Negeri 1 Banyuasin III Kabupaten Banyuasin". Penelitian dilakukan untuk mengetahui apakah ada pengaruh dan seberapa besar pengaruh peran komite sekolah dan program BOS terhadap kualitas pendidikan. Dan penelitian ini menggunakan metode korelasi parsial.

3. Ramadhani dan Suparno [8], "Pengaruh Sistem Pengendalian Internal Pemerintah (SPIP) Dan Peran Komite Sekolah Terhadap Pencegahan Fraud Pengelolaan Dana Bantuan Operasional Sekolah (BOS) Pada SMP Negeri di Banda Aceh". Penelitian ini bertujuan untuk mengetahui pengaruh Sistem Pengendalian Intern Pemerintah (SPIP) dan peran komite sekolah terhadap pencegahan kecurangan pengelolaan dana operasional sekolah (BOS). Penelitian ini menggunakan metode sensus, hasil yang didapat dari penelitian ini menunjukkan bahwa baik secara parsial Sistem Pengendalian Intern Pemerintah (SPIP) dan peran komite sekolah berpengaruh signifikan terhadap pencegahan kecurangan pengelolaan dana operasional sekolah (BOS) Sekolah Menengah Pertama di Banda Aceh.

\section{Metode Penelitian}

Populasi dan sampel yang diteliti adalah 158 guru SD Negeri di Kota Tangerang. Besar sampel ditentukan dengan rumus Slovin sebagai berikut:

Ket:

$$
n=\frac{N}{1+N(e)^{2}}
$$

$\mathrm{n}=$ Jumlah elemen atau anggota sampel

$\mathrm{N}=$ Jumlah unsur atau anggota populasi

$\mathrm{e}=$ Tingkat kesalahan 
terdapat populasi dalam penelitian yang berjumlah 158 orang dan presisi telah ditetapkan atau tingkat signifikansinya 0,05 atau 5\%, maka rumus besarnya sebuah sampel pada penelitian ini adalah:

Terdapat populasi dalam penelitian yang berjumlah 158 guru dan presisi telah ditetapkan atau tingkat signifikansi 0,05 atau 5\%, sehingga rumus besar sampel dalam penelitian ini adalah:

$$
\begin{gathered}
n=\frac{N}{1+N(e)^{2}} \\
n=\frac{158}{1+158(0,05)^{2}} \\
n=113.2616 \text { dibulatkan } 115
\end{gathered}
$$

Jadi total jumlah responden dalam penelitian ini adalah 115 guru.

Untuk menentukan sampel yang akan digunakan dalam penelitian, terdapat berbagai teknik pengambilan sampel yang digunakan. Penelitian ini peneliti menggunakan probability sampling dengan jenis simple random sampling

\section{Variabel Independen atau Variabel Bebas (X) dan Variabel Dependen atau Variabel Terikat (Y)}

Variabel bebas dalam penelitian ini adalah peran komite dan pengawas sekolah. Ini dapat dijelaskan secara umum sebagai berikut:

Peran Komite Sekolah (X1) memiliki beberapa indikator yang terdiri dari:

a) Memberikan pertimbangan dalam mengambil keputusan dan menyusun program kegiatan sekolah.

b) Memberi masukan atas rekomendasi Rencana Anggaran Pendidikan dan Belanja Sekolah.

c) Dukungan dalam memobilisasi dukungan keuangan dan memantau kondisi tenaga kependidikan.

d) Mengontrol keputusan pendidikan dan proses perencanaan.

e) Untuk mengakomodasi berbagai kebutuhan pendidikan yang diajukan oleh masyarakat.

Peran Pengawas Sekolah (X2) memiliki beberapa indikator yang terdiri dari:

a) Anggaran sekolah mengacu pada peraturan pemerintah pusat dan daerah

b) Membina Panitia Bantuan Operasional Sekolah dalam pengelolaan keuangan sekolah yang transparan, efisien dan akuntabel.

c) Pelaksanaan pembuatan laporan keuangan yang dilakukan sekolah kepada pemerintah dan stakeholders.

d) Pengawas melakukan koreksi jika ada penyimpangan.

e) Mengendalikan aktivitas institusi pendidikan dalam rencana RAPBS.

Terdapat beberapa indikator dalam pengelolaan dana Bantuan Operasional Sekolah (Y), yaitu:

a) Keterlibatan guru dalam pengelolaan dana.

b) Bisa dipertanggungjawabkan.

c) Kelola sesuai dengan manual Bantuan Operasional Sekolah.

d) Pelaksanaan Rencana Anggaran Pendidikan dan Belanja Sekolah.

e) Mengelola secara transparan dan akuntabel.

\section{Analisis Regresi Linier Berganda}

Sebuah metode Analisis digunakan untuk menguji pengaruh komite sekolah dan pengawas sekolah yang nantinya di rumuskan sebagai berikut: 


$$
Y=\alpha+\beta 1 X_{1}+\beta 2 X_{2}+\epsilon
$$

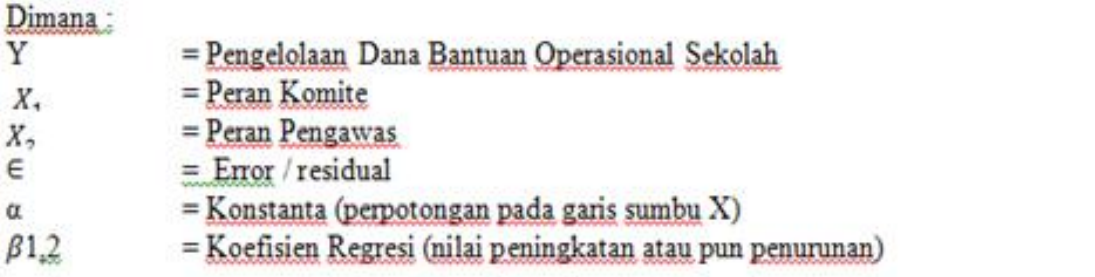

\section{Uji $R^{2}$ (Koefisien Determinasi)}

Setiap penelitian memiliki nilai koefisien $R^{2}$ yang memiliki interval nol sampai satu $\left(0 \leq R^{2} \leq 1\right)$. Jika semakin besar $R^{2}$ (mendekati 1 ), maka semakin baik hasil untuk model regresi akan semakin mendekati 0 . Kemudian penentuan nilai variabel independen secara keseluruhan tidak dapat menjelaskan variasi koefisien determinasi variabel $\left(R^{2}\right)[10]$

\section{Uji Signifikan Parameter Individual (Uji Statistik t)}

Dalam penelitian ini, untuk mengetahui dan menentukan kebenaran hipotesis, diperlukan langkahlangkah sebagai berikut::

a) Tentukan definisi hipotesis

$H_{o}: \beta_{1}=\beta_{2}=0$ : koefisien $\mathrm{X}$ secara bersama-sama tidak berpengaruh signifikan terhadap variabel $\mathrm{Y}$.

$H_{o}: \beta_{1} \neq \beta_{2} \neq 0$ : variabel $\mathrm{X}$ secara bersama-sama terbukti berpengaruh signifikan terhadap variabel $\mathrm{Y}$.

b) Tentukan tingkat signifikansi $(\alpha=0,05)$

c) Tentukan kriteria hipotesis

$H_{o}$ ditolak, jika $f_{\text {hitung }}>\alpha=0,05$

$H_{o}$ diterima, jika $f_{\text {hitung }}<\alpha=0,05$

d) Menarik kesimpulan atas hasil pengujian hipotesis

Kesimpulannya adalah $H_{o}$ diterima atau $H_{o}$ ditolak.

\section{Uji Signifikan Simultan (Uji Statistik F)}

Pengujian statistik F untuk menunjukkan apakah kedepannya setiap variabel independen yang dimasukkan dalam model penelitian dapat memiliki pengaruh yang secara simultan berperan terhadap variabel dependen. Contohnya adalah sebagai berikut :

a) Tentukan definisi hipotesis.

$H_{o}: \beta_{1}=\beta_{2}=0$ : variabel $\mathrm{X}$ secara bersama-sama tidak berpengaruh signifikan terhadap variabel Y.

$H_{o}: \beta_{1} \neq \beta_{2} \neq 0$ : variabel $\mathrm{X}$ secara bersama-sama terbukti berpengaruh signifikan terhadap variabel $Y$.

b) Tentukan tingkat signifikansi $(\alpha=0,05)$

c) Tentukan kriteria hipotesis

$H_{o}$ ditolak, jika $f_{\text {hitung }}>\alpha=0,05$

$H_{o}$ diterima, jika $f_{\text {hitung }}<\alpha=0,05$

d) Menarik kesimpulan atas hasil pengujian hipotesis

Kesimpulannya adalah $H_{o}$ diterima atau $H_{o}$ ditolak. 


\section{Hasil dan Pembahasan}

a) Pengaruh Peran Komite Sekolah terhadap Pengelolaan Dana BOS.

Berdasarkan Uji t dalam penelitian ini variabel $\left(X_{1}\right)$ memiliki nilai signifikan sebesar $0,015<0,05$, dan dapat disimpulkan bahwa $H_{0}$ ditolak sedangkan $H_{1}$ diterima yang artinya variabel peran komite sekolah $\left(X_{1}\right)$ berpengaruh positif terhadap pengelolaan dana BOS di Sekolah Dasar Negeri (Y).

b) Pengaruh Peran Pengawas Sekolah Terhadap Pengelolaan Dana BOS.

Berdasarkan Uji t dalam penelitian ini variabel $\left(X_{2}\right)$ memiliki nilai signifikan $0,000<0,05$, dan dapat disimpulkan bahwa $H_{0}$ ditolak sedangkan $H_{1}$ diterima yang artinya variabel peran komite sekolah komite $\left(X_{2}\right)$ berpengaruh positif terhadap pengelolaan dana BOS di Sekolah Dasar Negeri (Y).

c) Pengaruh Peran Komite dan Pengawas Sekolah Terhadap Pengelolaan Dana BOS.

Berdasarkan hasil uji regresi berganda dalam penelitian ini terlihat bahwa variabel komite dan pengawas sama dengan nol, sehingga pengaruhnya terhadap pengelolaan dana BOS di sekolah dasar negeri sebesar 9,813. Dengan hasil tersebut, peneliti dapat menunjukkan besarnya pengaruh kedua variabel $\mathrm{X}$ dan memegang peranan yang sangat penting dalam pelaksanaan dana BOS. Dengan demikian hipotesis yang diajukan sebelumnya terbukti berpengaruh positif.

\section{Uji Instrumen Penelitian}

a) Uji Validitas Komite Sekolah.

Hasil Pengujian validitas variabel peran komite sekolah terdapat rekapitulasi jawaban responden atas pengambilan sampel angket dan variabel peran komite sekolah disajikan pada tabel berikut::

Gambar 3. Tabel Hasil Pengujian Validitas Variabel Peran Komite Sekolah

\begin{tabular}{|c|c|c|c|}
\hline Item & $\mathrm{r}$ hitung & $\mathrm{r}$ tabel $(\mathrm{n}=115)$ & Keterangan \\
\hline $\mathrm{X} 1.1$ & 0,689 & 0,196 & Valid \\
\hline $\mathrm{X} 1.2$ & 0,555 & 0,196 & Valid \\
\hline $\mathrm{X} 1.3$ & 0,415 & 0,196 & Valid \\
\hline $\mathrm{X} 1.4$ & 0,588 & 0,196 & Valid \\
\hline $\mathrm{X} 1.5$ & 0,464 & 0,196 & Valid \\
\hline
\end{tabular}

Sumber: Hasil Olah Data SPSS

Dari gambar di atas terlihat bahwa nilai $r_{\text {hitung }}>$ nilai $r_{\text {tabel }}$ yang menyatakan peran variabel komite sekolah sudah valid.

b) Uji Validitas Pengawas Sekolah

Hasil Pengujian validitas variabel peran pengawas sekolah terdapat rekapitulasi jawaban responden atas pengambilan sampel angket dan variabel peran komite sekolah.

Gambar 4. Tabel Hasil Pengujian Validitas Variabel Peran Pengawas Sekolah

\begin{tabular}{|c|c|c|c|}
\hline Item & $\mathrm{r}$ hitung & $\mathrm{r}$ tabel $(\mathrm{n}=115)$ & Keterangan \\
\hline $\mathrm{X} 2.1$ & 0,452 & 0,196 & Valid \\
\hline $\mathrm{X} 2.2$ & 0,609 & 0,196 & Valid \\
\hline X3.3 & 0,711 & 0,196 & Valid \\
\hline X3.4 & 0,712 & 0,196 & Valid \\
\hline X2.5 & 0,571 & 0,196 & Valid \\
\hline
\end{tabular}

Sumber: Hasil Olah Data SPSS

Dari gambar diatas terlihat bahwa nilai $r_{\text {hitung }}>$ nilai $r_{\text {tabel }}$ menyatakan bahwa peran pengawas sekolah sudah valid. 
c) Uji Validitas Pengelolaan Dana BOS.

Hasil uji validitas variabel pengelolaan dana bantuan operasional sekolah.

Gambar 5. Tabel Hasil Pengujian Validitas Pengelolaan Dana BOS

\begin{tabular}{|c|c|c|c|}
\hline Item & r hitung & $\mathrm{r}$ tabel $(\mathrm{n}=115)$ & Keterangan \\
\hline Y1 & 0,669 & 0,196 & Valid \\
\hline Y2 & 0,677 & 0,196 & Valid \\
\hline Y3 & 0,634 & 0,196 & Valid \\
\hline Y4 & 0,580 & 0,196 & Valid \\
\hline Y5 & 0,492 & 0,196 & Valid \\
\hline
\end{tabular}

Sumber: Hasil Olah Data SPSS

Dari gambar diatas dapat dilihat bahwa nilai $r_{\text {hitung }}>$ nilai $r_{\text {tabel }}$. menyatakan bahwa variabel peran pengawas sekolah dinyatakan valid.

d) Uji Reliabilitas untuk variabel X dan Y

Pengujian reliabilitas menggunakan rumus koefisien alpha, yang dapat diukur menggunakan pengujian statistik untuk melihat nilai Cronbach Alpha.

Gambar 6. Tabel Hasil Uji Reliabilitas Variabel X dan Y

\begin{tabular}{|c|c|c|c|}
\hline Variabel & Cronbach Alpha & Kriteria & Keterangan \\
\hline Peran Komite Sekolah & 0,698 & 0,6 & Reliabel \\
\hline Peran Pengawas Sekolah & 0,739 & 0,6 & Reliabel \\
\hline Pengelolaan dana BOS & 0,731 & 0,6 & Reliabel \\
\hline
\end{tabular}

Sumber: Hasil Olah Data SPSS

Gambar di atas menunjukkan bahwa secara keseluruhan nilai Cronbach Alpha untuk variabel peran komite sekolah, peran pengawas sekolah dan pengelolaan dana BOS lebih besar dari 0,6 .

\section{Uji Analisis Regresi Linier Berganda}

Analisis regresi linier berganda peneliti gunakan untuk mengetahui hubungan antara variabel independen dengan variabel dependen apakah masing-masing variabel berhubungan positif atau negatif. Hasil pengujian regresi linier berganda ditunjukkan pada tabel berikut::

Gambar 7. Tabel Hasil Analisis Regresi Linier Berganda

Coefficients $^{*}$

\begin{tabular}{|l|r|r|r|r|r|}
\hline \multirow{2}{*}{ Model } & \multicolumn{2}{|c|}{ Unstandardized Coefficients } & $\begin{array}{c}\text { Standardized } \\
\text { Coefficients }\end{array}$ & & \\
\cline { 2 - 4 } & \multicolumn{1}{|c|}{$\mathrm{B}$} & \multicolumn{1}{|c|}{ Std. Error } & \multicolumn{1}{c|}{ Beta } & \multicolumn{1}{c|}{ Sig. } \\
\hline $1 \quad$ (Constant) & 9.813 & 2.012 & & 4.877 & .000 \\
x1 & .196 & .079 & .209 & 2.481 & .015 \\
x2 & .362 & .074 & .412 & 4.897 & .000 \\
\hline
\end{tabular}

Sumber Hasil Olahan Data SPSS

Hasil pengujian analisis regresi linier berganda yang diperoleh dari penelitian ini adalah :

$$
Y=9,813+0,196 X_{1}+0,362 X_{2}
$$


Dan dapat dijelaskan bahwa:

a) Nilai konstanta regresi sebesar 9,813, menunjukkan jika peran komite sekolah dan peran pengawas sekolah sama dengan nol, maka nilai Pengelolaan Dana BOS sebesar 9,813.

b) Variabel peran komite sekolah memiliki nilai 0,196 dan bertanda positif. Artinya peningkatan peran pengurus $\left(X_{1}\right)$ akan berdampak pada peningkatan pengaruh pengelolaan dana BOS (Y). Begitu pula sebaliknya, jika peran komite sekolah menurun, maka pelaksanaan pengelolaan dana BOS juga akan mengalami penurunan jumlahnya dengan asumsi angka $X_{2}$ tetap.

c) Variabel peran pengawas sekolah memiliki nilai koefisien 0,3262 dan bertanda positif. Artinya peningkatan peran pengawas $\left(X_{2}\right)$ akan berdampak pada peningkatan pengaruh pengelolaan dana BOS (Y). Begitu pula sebaliknya, jika peran pengawas menurun maka pelaksanaan pengelolaan dana BOS juga akan menurun, dengan asumsi angka $\mathrm{X}_{1}$ tetap

\section{Uji Koefisien Determinasi $\left(R^{2}\right)$}

Untuk mengetahui seberapa besar pengaruh variabel independen terhadap variabel dependen. Kemudian hasil pengujian koefisien determinasi $\left(R^{2}\right)$ terdapat pada gambar tabel sebagai berikut::

Gambar 8. Tabel Hasil Pengujian Koefisien Determinasi $\left(R^{2}\right)$

\begin{tabular}{|l|r|r|c|r|r|}
\hline Model & $\mathrm{R}$ & $\mathrm{R}$ Square & $\begin{array}{c}\text { Adjusted } \mathrm{R} \\
\text { Square }\end{array}$ & $\begin{array}{c}\text { Std. Error of the } \\
\text { Estimate }\end{array}$ & Durbin-Wats on \\
\hline 1 & $.504^{\circ}$ & .254 & .240 & .34611 & 1.915 \\
\hline
\end{tabular}
a. Predictors: (Constant), $\times 2, \times 1$
b. Dependent Variable: $y$

Sumber: Hasil Olah Data SPSS

Dari hasil pengujian koefisiensi determinasi $\left(R^{2}\right)$ dapat diketahui bahwa hasil koefisien determinasi $\left(R^{2}\right)$ sebesar 0.254 dan variable Y $25,4 \%$ yang dipengaruhi oleh variabel $X_{1}$ dan variabel $X_{2}$ sisanya $74,6 \%(100 \%-25,4 \%)$ dipengaruhi oleh variabel lain yang tidak diteliti selain peran komite sekolah dan peran pengawas sekolah, seperti partisipasi komite dan akuntabilitas dan transparasi dalam manajemen.

\section{Uji Signifikan Parameter Individual (Uji Statistik t)}

Uji $\mathrm{t}$ digunakan untuk mengetahui apakah masing-masing independen secara individual mempengaruhi variabel dependen. Hasil penelitian tentang uji t ditunjukkan pada gambar tabel sebagai berikut::

Gambar 8. Tabel Hasil Pengujian t

\begin{tabular}{|c|c|c|c|c|c|c|}
\hline \multicolumn{7}{|c|}{ Coefficients ${ }^{2}$} \\
\hline & & Unstandardized 0 & Coefficients & $\begin{array}{c}\text { Standardized } \\
\text { Coefficients }\end{array}$ & & \\
\hline \multicolumn{2}{|c|}{ Model } & $\mathrm{B}$ & Std. Error & Beta & $\mathrm{t}$ & Sig. \\
\hline & (Constant) & 9.813 & 2.012 & & 4.877 & .000 \\
\hline & $\mathrm{x} 1$ & .196 & .079 & .209 & 2.481 & .015 \\
\hline & $x 2$ & .362 & .074 & .412 & 4.897 & .000 \\
\hline
\end{tabular}

Sumber: Hasil Olah Data SPSS 
Berdasarkan tabel hasil Pengujian t berikut dapat disimpulkan bahwa::

a) Pengaruh Peran Komite sekolah $\left(X_{1}\right)$

Berdasarkan data tabel diatas, variabel peran komite sekolah $\left(X_{1}\right)$ memiliki nilai signifikansi sebesar $0,015<0,05$ yang berarti peran komite sekolah $\left(X_{1}\right)$ berpengaruh positif terhadap pengelolaan dana BOS (Y).

Pernyataan berikut menunjukkan bahwa sesuai dengan hipotesis yang telah diujikan yaitu :

$H_{1}$ : Peran Komite Sekolah berpengaruh signifikan terhadap pengelolaan dana BOS di Sekolah Dasar Negeri.

b) Pengaruh Peran Pengawas Sekolah $\left(X_{2}\right)$

Berdasarkan data tabel diatas, variabel peran komite sekolah $\left(X_{2}\right)$ memiliki nilai signifikansi sebesar $0,000<0,05$ yang berarti peran pengawas sekolah $\left(X_{2}\right)$ berpengaruh positif terhadap pengelolaan dana BOS (Y).

Pernyataan berikut menunjukkan bahwa sesuai dengan hipotesis yang telah diujikan yaitu:

$\mathrm{H}_{2}$ : Peran pengawas sekolah berpengaruh signifikan terhadap pengelolaan dana BOS di Sekolah Dasar Negeri

\section{Uji Signifikan Simultan (Uji Statistik F)}

Dalam melakukan tahap pengujian penelitian yaitu uji f, jika kemudian menggunakan tingkat signifikansi $5 \%$ dan nilai probabilitas $<0,05$, maka penelitian tersebut dapat dikatakan memiliki pengaruh yang signifikan secara simultan antara variabel $\mathrm{X}$ terhadap variabel $\mathrm{Y}$.

Namun jika nilai uji f menunjukkan signifikansi> 0,05 maka secara simultan penelitian tidak dapat mempengaruhi signifikansi antara variabel $\mathrm{X}$ terhadap variabel $\mathrm{Y}$. untuk membuktikannya dapat dilihat dari uji F pada gambar tabel ANOVA berikut::

\section{Gambar 9. Tabel Hasil Pengujian $\mathrm{f}$}

ANOVA $^{\circ}$

\begin{tabular}{|c|c|c|c|c|c|c|}
\hline \multicolumn{2}{|c|}{ Model } & Sum of Squares & df & Mean Square & $\mathrm{F}$ & Sig. \\
\hline \multirow[t]{3}{*}{1} & & 4.559 & 2 & \multirow{3}{*}{$\begin{array}{r}2.280 \\
.120\end{array}$} & \multirow[t]{3}{*}{19.030} & \multirow[t]{3}{*}{$.000^{\circ}$} \\
\hline & Residual & 13.416 & 112 & & & \\
\hline & Total & 17.976 & 114 & & & \\
\hline
\end{tabular}

Berdasarkan data diatas maka hasil Pengujian F mempunyai nilai signifikansi $0,000<0,05$ maka dapat disimpulkan bahwa data tersebut sesuai dengan hipotesis yang telah diuji yaitu::

$\mathrm{H}_{3}$ : Peran komite sekolah dan pengawas berpengaruh signifikan terhadap pengelolaan dana BOS di Sekolah Dasar Negeri

\section{Kesimpulan}

Berdasarkan hasil pembahasan dalam penelitian tentang analisis pengaruh peran komite sekolah dan pengawas terhadap pengelolaan dana BOS di sekolah dasar negeri khususnya kota tangerang sebagai berikut:

1. Peran Komite Sekolah terbukti berpengaruh signifikan dan positif terhadap pengelolaan dana BOS di sekolah dasar negeri, khususnya di Kota Tangerang. 
2. Peran pengawas sekolah terbukti berpengaruh signifikan dan positif terhadap pengelolaan dana BOS di sekolah dasar negeri khususnya di Kota Tangerang.

3. Peran komite sekolah dan pengawas terbukti berpengaruh signifikan dan positif terhadap pengelolaan dana BOS di sekolah dasar negeri, khususnya di Kota Tangerang.

\section{Daftar Pustaka}

[1] Kepmendiknas. 2015. Surat Keputusan Menteri Pendidikan Nasional Nomor: 004/U/2015. Tentang Revisi Dewan Pendidikan dan Komite Sekolah. Jakarta: Ditjen Dikdasmen

[2] Sri Mulyani et.all.2018. Sistem Informasi Akuntansi: Aplikasi Di Sektor Publik. Bandung: Unpad Press

[3] Rahayu, Sri. 2020. Penganggaran Dana Bantuan Operasional Sekolah: Perspektif New Institutional Sociology. Malang: Peneleh Anggota IKAPI

[4] Sitorus, A., \& Kholipah, S. 2018. SUPERVISI PENDIDIKAN: Teori dan Pengaplikasian. Lampung: Swalova Publishing

[5] Rahayu, Sri. 2020. Penganggaran Dana Bantuan Operasional Sekolah: Perspektif New Institutional Sociology. Malang: Peneleh Anggota IKAPI.

[6] Indahri, Yulia. 2019. Peran Sekolah Dan Masyarakat Dalam Pelaksanaan Program Bantuan Operasional Sekolah. Aspirasi: Jurnal Masalah-Masalah Sosial, 10(1) 49-60

[7] Rukanto. 2018. Pengaruh Peran Komite Sekolah Dan Program Bantuan Operasional Sekolah (Bos) Terhadap Mutu Pendidikan Di SMA Negeri 1 Banyuasin III Kabupaten Banyuasin. Thesis, Program Studi Manajemen Pendidikan Program Pascasarjana, Universitas PGRI Palembang

[8] Rahmadhani, L., \& Suparno, S.2020. Pengaruh Sistem Pengendalian Internal Pemerintah (SPIP) Dan Peran Komite Sekolah Terhadap Pencegahan Fraud Pengelolaan Dana Bantuan Operasional Sekolah (BOS) Pada SMP Negeri di Banda Aceh. Jurnal Ilmiah Mahasiswa Ekonomi Akuntansi (JIMEKA), 5(3) 400-411 